\title{
Herbal extracts and symbiotic mixture replacing antibiotics in piglets at the initial phase ${ }^{1}$
}

\author{
Márcio Gilberto Zangeronimo², Vinícius de Souza Cantarelli³, Elias Tadeu Fialho ${ }^{3}$, Níkolas de \\ Oliveira Amaral ${ }^{4}$, Hebert Silveira ${ }^{3}$, Leandro de Melo Pereira ${ }^{3}$, Luciano José Pereira ${ }^{2}$ \\ 1 Financiado pela Duas Rodas Industrial LTDA com apoio da Fapemig. \\ 2 Departamento de Medicina Veterinária, Universidade Federa de Lavras, Lavras, MG. \\ ${ }^{3}$ Departamento de Zootecnia - UFLA. \\ 4 Instituto Federal de Educação, Ciência e Tecnologia do Sul de Minas - Campus Machado, Machado, MG.
}

\begin{abstract}
The objective of this work was to evaluate the use of vegetable extract based addictives associated or not to symbiotics as an alternative for antibiotic as growth promoters for piglets at initial phase. It was used 125 pigs of commercial genetic line with initial weight of $7.4 \pm 1.1 \mathrm{~kg}$, weaned at 20 days of age, during 50 days. The experimental design used was randomized blocks (initial weight), with five treatments and five replicates with five animals per experimental unit. The experimental diets were a basal diet, without additive, and other four diets, one diet containing antibiotic (colistin + zinc oxide); diet with $0.3 \%$ of a symbiotic mixture; diet with $0.3 \%$ of a symbiotic mixture plus $0.05 \%$ of herbal mix (plant extracts and microencapsulated essential oils); and another diet with $0.3 \%$ of symbiotic mixture plus $0.1 \%$ of herbal mixture. It was observed that the use of the symbiotic mixture associated to $0.05 \%$ of herbal mixture showed positive results, similar to the ones obtained with diets containing antibiotics for the final weight, average weight gain, average daily feed intake and $\mathrm{pH}$ of stomach and diarrhea incidence. The use of symbiotics promoted smaller vilous:depth crypt ratio, except when associated to $0.1 \%$ of herbal mixture, which was similar to the diet without addictives. There was no differences in the feed conversion, coliform and lactobacillus count in the jejune and in the cecum and in the $\mathrm{pH}$ of cecum. The use of herbal mixture associated to symbiotic is a viable alternative for replacing the use of antibiotics as growth promoters for piglets in the initial phase. However, the concentration of the herbal mixture is an important factor to be considered.
\end{abstract}

Key Words: growth promoters, performance, prebiotic, probiotic, swine

\section{Extratos herbais e mistura simbiótica em substituição aos antibióticos para suínos na fase inicial}

\begin{abstract}
RESUMO - O objetivo neste trabalho foi avaliar o uso de aditivos à base de extratos vegetais associados ou não ao uso de simbióticos como alternativa aos antibióticos como promotores de crescimento para suínos na fase inicial. Foram utilizados 125 leitões de genética comercial, com peso inicial de 7,4 $\pm 1,1 \mathrm{~kg}$, desmamados aos 20 dias, durante 50 dias. O delineamento experimental foi o de blocos casualizados (peso inicial) com cinco tratamentos e cinco repetições com cinco animais por unidade experimental. As dietas experimentais foram uma ração basal, sem aditivo, e outras quatro, uma contendo antibiótico (colistina + óxido de zinco); outra com $0,3 \%$ de uma mistura simbiótica; outra com 0,3\% da mistura simbiótica e 0,05\% de uma mistura herbal (extrato de plantas e óleos essenciais microencapsulados) e outra com 0,3\% da mistura simbiótica e 0,10\% da mistura herbal. Foi observado que o uso da mistura simbiótica associada a 0,05\% da mistura herbal teve resultados positivos e semelhantes aos obtidos com as dietas contendo antibióticos quanto ao peso final, ganho de peso, consumo médio diário, pH do estômago e incidência de diarreia. O uso de simbióticos promoveu menor relação vilosidade:cripta, exceto quando associado a $0,1 \%$ da mistura herbal, que se assemelhou à dieta sem aditivos. Não houve diferenças na conversão alimentar, na contagem de coliformes e lactobacilus no jejuno e no ceco e no pH do ceco. O uso de uma mistura herbal associada a simbióticos é uma alternativa viável para substituição ao uso de antibióticos como promotores de crescimento para suínos na fase inicial. No entanto, a concentração da mistura herbal é um fator importante a ser considerado.
\end{abstract}

Palavras-chave: desempenho, prebiótico, probiótico, promotores de crescimento, suínos

\section{Introduction}

The growth of intensive pig farming has forced the use of growth promoters additives to ensure satisfactory performance of the animals and to reduce the economic losses caused by pathogens. In this sense, antibiotics have been used extensively. However, there is demand for products that can replace these additives, due to the 
possibility of residues in the carcasses and the emergence of resistant bacteria.

The health of piglets in the early stages is important for the development of animals in later phases. The change in environment and diet after weaning is a challenge, particularly to intestinal health, which often culminates in subclinical diseases which harm the development. However, several substances have the capacity to improve the performance of weanling pigs (Estienne et al., 2005), although the results are not always satisfactory.

Symbiotic are probiotic microorganisms associated to specific prebiotic substances that stimulate their activity and development. The exact mechanism in which this combination is preformed is not completely understood and it may occur by the production of inhibitory compounds such as lactic acid, or by competition for nutrients and adhesion sites (Alexopoulos et al., 2004).

Few studies have been conducted in Brazil to prove the action of plant extracts as growth promoters in pigs. The results are quite controversial and inconclusive, especially when considering the types and characteristics of the products used, environmental conditions, physiological status of animals, among others.

In vitro studies conducted by Dorman \& Deans (2000) have shown pronounced antimicrobial effect of essential oils of clove, thyme and oregano on pathogens and this may be linked to changes in permeability and integrity of the bacterial cell membrane (Lambert et al., 2001). By combining this knowledge to the associated use with symbiotic, the effects obtained and the mechanisms of action in animal production are still unknown.

Thus, the objective of this study was to evaluate the use of symbiotics added or not to an herbal mixture, in place of antibiotics, for post-weaning piglets and its effects on performance and microbiological and physiological parameters of the gastrointestinal tract of animals.

\section{Material and Methods}

The experiment was conducted at the Centro Experimental de Suínos in Departamento de Zootecnia at Universidade Federal de Lavras.

It was used 125 piglets (males and females) from commercial line (Agroceres-PIC) with an initial weight of $7.4 \pm 1.1 \mathrm{~kg}$, weaned at 20 days of age. The animals were housed during 50 days in groups of five (three males and two females) in the nursery stall with slatted suspended floor stalls at $1.20 \mathrm{~m}$ of height and dimensions of $2.00 \times 1.20 \mathrm{~m}$, equipped with semi-automatic feeder and drinker dummy type. The internal temperature of the room was controlled through the handling of windows, heating lamps and fans after the measurement of daily maximum and minimum temperatures.

The experimental design was conducted in randomized blocks (initial weight), with five treatments and five replications. The experimental diets were: basal diet; basal diet with antibiotic (colistin + zinc oxide); basal diet with $0.3 \%$ of a symbiotic mixture (probiotic + prebiotic); basal diet with $0.3 \%$ of a symbiotic mixture plus $0.05 \%$ of herbal mix (plant extracts and microencapsulated essential oils); and basal diet with $0.3 \%$ of symbiotic mixture plus $0.1 \%$ of herbal mixture.

Diets were isocaloric and isonutrient formulated based on corn, gelatinized corn, soybean meal and powdered milk, and supplemented with vitamins and minerals to meet the requirements of high genetic piglets (pre-starter and initial phase), according to Rostagno et al. (2005) (Table 1).

The animals were weighed at the beginning and at the end of the experiment to determine the weight gain. Feed supply and food scraps were measured daily to determine feed intake. Feed:gain ratio was determined by the feed intake/weight gain ratio.

It was also conducted the daily monitoring of the diarrhea incidence by using the methodology described by Vassallo et al.(1997): 0 - normal feces; 1 - soft feces, 2 - paste feces and 3 - aqueous feces (diarrhea). These assessments were made daily in the morning, by the same qualified person who registered the occurrence or not of these types of feces in each experimental unit.

From the ninth to the $20^{\text {th }}$ day of the experiment, one animal per experimental unit was slaughtered after electric desensitization to measure the physiological, morphological and microbiological parameters of gastrointestinal tract. Immediately after slaughter and evisceration, $\mathrm{pH}$ of stomach and cecum contents were measured through incision in the ventral part of the organs, after homogenization of their contents. For this measurement, the F-1002 pHmeter was used.

For the evaluation of microbiological parameters, sections of the jejunum and cecum were isolated with a cord soaked in iodine alcohol, separated in a sterile table and stored in sterile plastic bags, put in isothermal box and immediately taken to a specialized laboratory in Belo Horizonte-MG, where the analysis for lactic acid bacteria and total coliforms were performed.

For histological tract, a fragment of approximately $2.0 \mathrm{~cm}$ was removed from the middle third of the jejunum. Immediately, the samples were washed in distilled water, identified and fixed in Boin (aqueous saturated of picric acid, formaldehyde and acetic acid) for 24 hours. After, 
Table 1 - Centesimal composition and calculated values of experimental diets

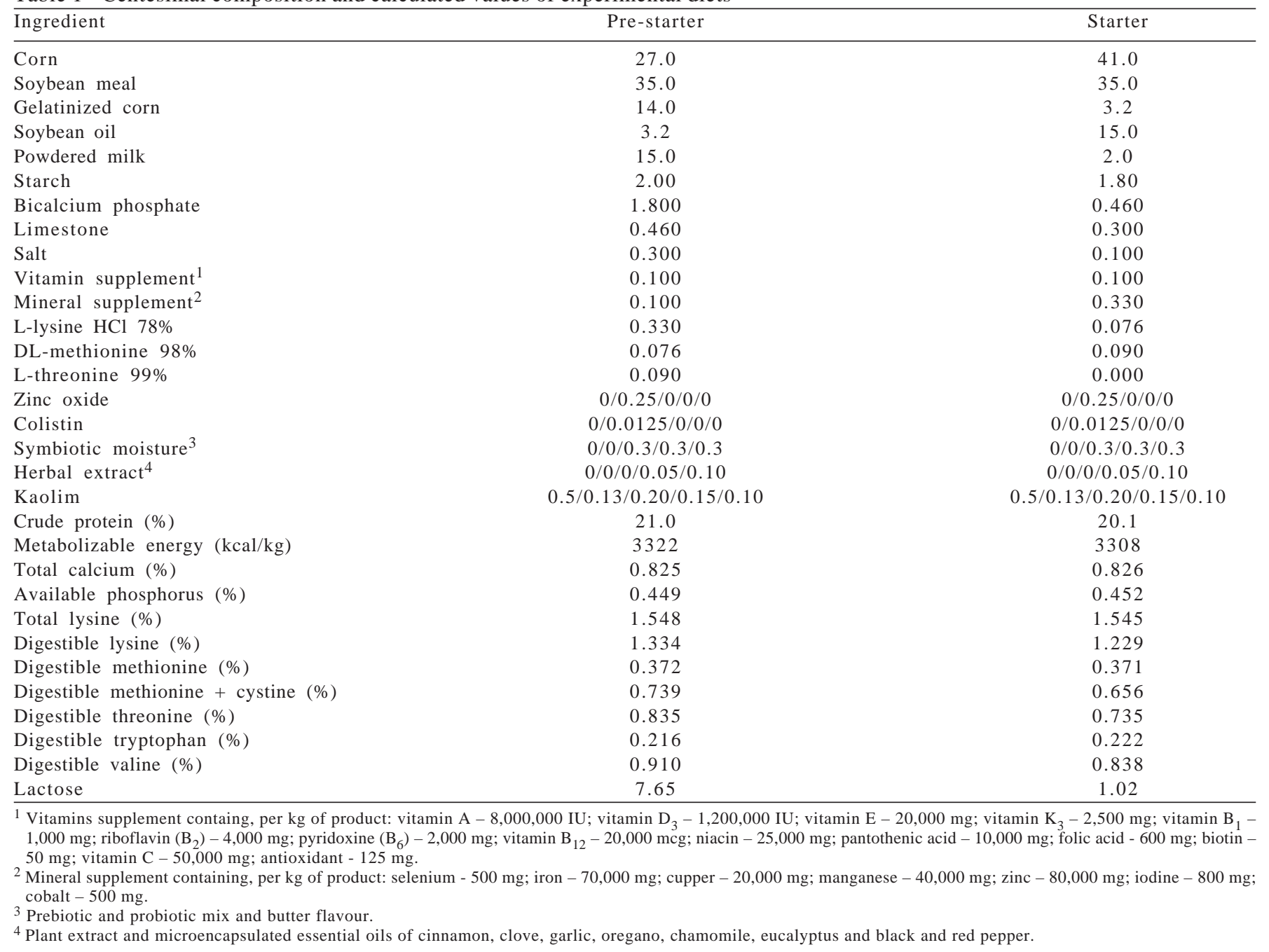

the samples were washed and preserved in 70\% ethanol solution for future analysis. The preparation of slides was performed at the Laboratório de Patologia Veterinária at UFLA by using the technique described by Junqueira \& Junqueira (1983) with some adjustments.

The analyzed variables were average daily gain (ADG), average daily feed intake (ADFI), feed:gain, villi height, crypt depth and villi:crypt ratio of jejunum; quantity of lactic bacteria and total fecal coliforms in the jejunum and cecum, $\mathrm{pH}$ of the stomach and cecum, hematocrit, quantity of white blood cell and total lymphocyte and serum urea. For microbial parameters, a nonparametric statistics (chi-square) was used and the means were compared by Kruskal-Wallis test. Other data were subjected to analysis of variance after normality test (Shapiro-Wilk) and the means were compared by SNK test at 5\%. All statistical analysis was performed by using the GLM procedure of SAS (SAS, 1998).

\section{Results and Discussion}

The isolated or combined additives in the diets did not affect $(P>0.05)$ the feed:gain ratio of the piglets, but there were differences $(\mathrm{P}<0.05)$ in the final weight, weight gain and feed intake (Table 2). The antibiotics as growth promoters showed better results but those were similar to the symbiotic associated with $0.05 \%$ of the herbal mix. The isolated use of symbiotic or the association at a high dose of herbal mix did not show good results for final weight and weight gain of the animals.

Similar results were observed by Utiyama et al. (2006), who observed no differences in feed:gain ratio, but higher feed intake and greater weight gain when antimicrobial agents were used in comparison to diets containing no additive or probiotic, prebiotic or plant extract based in garlic, clove, cinnamon, pepper, thyme, cinnamaldehyde and eugenol for piglets from 21 to 56 days of age. 
Table 2 - Performance of starter pigs fed diets containing antibiotics, symbiotics and herbal mix

\begin{tabular}{lccccccc}
\hline Variable $^{1}$ & $\begin{array}{c}\text { Without } \\
\text { addictive }\end{array}$ & Antibiotic & $\begin{array}{c}\text { Symbiotic } \\
\text { mix }\end{array}$ & $\begin{array}{c}\text { Symbiotic mix }+ \\
0.05 \% \text { of herbal mix }\end{array}$ & $\begin{array}{c}\text { Symbiotic mix }+ \\
0.1 \% \text { of herbal mix }\end{array}$ & CV (\%) & P \\
\hline Final weight (kg) & $27.15 \mathrm{ab}$ & $29.94 \mathrm{a}$ & $25.61 \mathrm{~b}$ & $28.58 \mathrm{ab}$ & $24.72 \mathrm{~b}$ & 8.16 & 0.0353 \\
Weight gain (g/day) & $403 \mathrm{ab}$ & $451 \mathrm{a}$ & $382 \mathrm{~b}$ & $429 \mathrm{ab}$ & $354 \mathrm{~b}$ & 10.45 & 0.0483 \\
Feed intake (g/day) & $665 \mathrm{~b}$ & $746 \mathrm{a}$ & $696 \mathrm{a}$ & $723 \mathrm{a}$ & $617 \mathrm{~b}$ & 7.28 & 0.0270 \\
Feed:gain & 1.68 & 1.66 & 1.84 & 1.69 & 1.65 & 7.95 & 0.3245 \\
\hline
\end{tabular}

${ }^{1}$ Means followed by different letters differ by SNK test $(\mathrm{P}<0.05)$.

$\mathrm{CV}=$ coefficient of variation.

Furthermore, Hermann et al. (2003) found no significant difference in performance of starter pigs using the extract of Echinacea purpurea and carbadox in relation to the control diet. Similar results were obtained by Fukayama et al. (2005) and Pedroso et al. (2005). This last work compared herbal extract based on thyme, clove and oregano in a combination with different concentrations of antimicrobial agents (colistin, bacitracin and olaquindox) and a basal diet without promoters.

With regard to the symbiotic, Budiño et al. (2006) observed better performance of piglets with the use of symbiotics, compared to the basal diet alone or with antibiotics or probiotics. The authors suggested that those results were related to a possible reduction of the coliforms in the jejunum. Nevertheless, they found no reduction in the incidence of diarrhea. On the other hand, Sanchez et al. (2006) found similar performance of the animals when they used probiotics, prebiotics or symbiotics compared to antibiotics.

The performance of the animals which received no additives was similar to the others. This fact indicated that the experimental conditions were favorable from the standpoint of health. This shows that besides the quantity of the herbal extract used, the environmental conditions also influence the variability of results in the literature.
Anyway, the higher performance of the animals in the nursery phase represents greater slaughter weight or a decrease in the number of days until slaughter.

The mechanisms of plant extracts in experiments with animals have not been fully clarified and verified. Santurio et al. (2007) found in in vitro experiments that essential oils from oregano and thyme are effective against Salmonella, but the variations among the serovars should be considered. According to these authors, the literature lacks studies that effectively classify the bactericidal activity of essential oils. In in vivo experiments, Namkung et al. (2004) also found a reduction of intestinal coliforms for piglets, but they have found no effect on intestinal morphology.

With respect to microbiological parameters of the jejunum and cecum, no effect $(\mathrm{P}>0.05)$ was observed among the different combinations of additives in the diets (Table 3). Numerically, data confirm the observation of Namkung et al. (2004), but the variation in the results of the present work did not permit the identification of statistical differences. At the same time, the highest concentration of the extract increased the number of Lactobacillus. This suggests that the antimicrobial effect of plant extracts influences directly the digestive physiology of animals.

Literature reports that the effect of the diets on the intestinal flora is more evident after weaning, when animals

Table 3 - Total coliform and Lactobacillus sp. in the jejunum and cecum of piglets on the 9th and 20th day post-weaning, receiving different addictive combinations in the diet

\begin{tabular}{|c|c|c|c|c|c|c|}
\hline Variable $^{1}$ & $\begin{array}{l}\text { Without } \\
\text { addictive }\end{array}$ & Antibiotic & $\begin{array}{l}\text { Symbiotic } \\
\operatorname{mix}\end{array}$ & $\begin{array}{l}\text { Symbiotic mix }+ \\
0.05 \% \text { of herbal mix }\end{array}$ & $\begin{array}{l}\text { Symbiotic mix }+ \\
0.1 \% \text { of herbal mix }\end{array}$ & $\mathrm{P}$ \\
\hline \multicolumn{7}{|c|}{ Coliforms $9^{\text {th }}$ day (CFU) } \\
\hline Jejune & 1151 & 1151 & 657 & 1513 & 1316 & 0.8763 \\
\hline Cecum & 703 & 946 & 418 & 465 & 182 & 0.6294 \\
\hline \multicolumn{7}{|c|}{ Coliforms $20^{\text {th }}$ day (CFU) } \\
\hline Jejune & 1482 & 619 & 1226 & 119 & 18 & 0.2386 \\
\hline Cecum & 1322 & 652 & 59 & 86 & 54 & 0.2654 \\
\hline \multicolumn{7}{|c|}{ Lactobacillus sp $9^{\text {th }}$ day (CFU) } \\
\hline Jejune & $3,650,000$ & $9,801,750$ & 45,330 & $18,975,028$ & $33,651,500$ & 0.2894 \\
\hline Cecum & 458 & 53,580 & 1,410 & 8,705 & 158 & 0.1812 \\
\hline \multicolumn{7}{|c|}{ Lactobacillus sp $20^{\text {th }}$ day (CFU) } \\
\hline Jejune & $6,326,750$ & $33,500,477$ & $12,560,875$ & $8,385,500$ & $46,700,000$ & 0.4423 \\
\hline Cecum & 79,006 & $30,048,000$ & 750,556 & 665,113 & $5,950,000$ & 0.3985 \\
\hline
\end{tabular}

${ }^{1}$ No effect by Kruskal-Walis test $(\mathrm{P}>0.05)$. 
are more susceptible to colonization by pathogenic bacteria. This is due to the sudden change of diet and environment yonder contact with other animal litters, which favors the microbial imbalance. Still, Namkung et al. (2004), Oetting et al. (2006) and Utiyama et al. (2006) observed no differences when using herbal extracts and antibiotics as growth promoters in the diets of piglets. According to studies cited by Pedroso et al. (2005), the intestinal microbiota is wide and only 400 species are known, many of which are rarely detected by traditional methods of cultivation. This fact may have created difficulties finding any statistical differences for this variable.

Jamroz \& Kamel (2002) suggested that supplementation with plant extracts increases the digestibility of nutrients and promotes a balanced microflora. This reduces the potential for adhesion of pathogens to the intestinal epithelium, representing one of mechanisms by which the symbiotic acts. According to Fuller et al. (1989), beneficial bacteria would be favored in the gastrointestinal tract, preventing colonization of pathogenic bacteria in the mucosa. Moreover, these pathogenic bacteria would also be harmed by the use of oligosaccharides (prebiotics) which bind to their sites of adhesion. It was verified, by the same authors, that some bacteria can also produce enzymes that enhance the digestion of nutrients, for example, lactase and galactosidase. Chesson (1994) proposed that probiotics may have immunomodulatory action due to the production of glycopeptides and other metabolites. Based on these arguments, it can be inferred that the environmental conditions which animals are subjected to and the presence of undesirable bacteria may directly influence the results.

Regarding the stomach and cecal $\mathrm{pH}$, no effect $(\mathrm{P}>0.05)$ of combinations of additives on the $\mathrm{pH}$ of the cecum of the animals on the $9^{\text {th }}$ and $20^{\text {th }}$ days was observed, although there were differences $(\mathrm{P}<0.05)$ in the $\mathrm{pH}$ of the stomach on the $20^{\text {th }}$ day of the experiment (Table 4). In this phase of the life of the animal, a lower $\mathrm{pH}$ is favorable to improve the conditions of the enzymes, and to discourage the growth of pathogenic microorganisms in the gastrointestinal tract.

Wang \& Bourne (1998) proposed that some herbal extracts can also stimulate the pancreatic secretion, which is linked to the improvement of nutrient digestibility. Lewis et al. (2004) and Oetting et al. (2006) founded no significant numerical increase of pancreas weight when using the herbal extracts. Lee et al. (2003) observed an increase of intestinal amylase activity in chickens at 21 days of age receiving a combination of plant extracts in the diet, and trypsin at 46 days of age, concluding that the sensitivity of the endogenous enzymes can be modified by the plant extracts according to the age of the animal. This could explain the results obtained by Oetting et al. (2006), who observed an increase in dry matter digestibility when testing herbal extract consisting of essential oil of clove, thyme and oregano, added to the active ingredients eugenol and carvacrol. This diet was compared to the control diet or one containing a combination of antimicrobials (olaquindox, colistin and bacitracin). However, the authors observed greater villi height and better performance of the animals when using antimicrobials in the diets.

A significant effect $(\mathrm{P}<0.05)$ for combinations of additives in jejunal morphometry (Table 5) was observed. On the ninth day of the experiment, there were greater villous heights with the use of antibiotics, symbiotic and symbiotic associated with the lower dose of the herbal extract. Despite the greater crypts depth at the twentieth day, there was less villous:crypt ratio in this period with these same diets. This may have promoted, to some extent, the absorption of nutrients and improved the performance of animals at this stage, explaining the results of weight gain obtained in this study.

The use of high concentration of herbal extract damaged the villous height in this period for an unknown reason. The non-increase of coliforms in this period ruled out the possibility of injury by microorganisms and the similarity between the crypts depths rule out the possibility of an inflammatory reaction. These results point again that the plant extracts can be used in diets for to replace

Table $4-\mathrm{pH}$ of the stomach and cecum of piglets on the $9^{\text {th }}$ and $20^{\text {th }}$ days of nursery receiving different experimental diets

\begin{tabular}{|c|c|c|c|c|c|c|c|}
\hline Variable $^{1}$ & $\begin{array}{l}\text { Without } \\
\text { addictive }\end{array}$ & Antibiotic & $\begin{array}{l}\text { Symbiotic } \\
\operatorname{mix}\end{array}$ & $\begin{array}{l}\text { Symbiotic mix }+ \\
0.05 \% \text { of herbal mix }\end{array}$ & $\begin{array}{l}\text { Symbiotic mix }+ \\
0.1 \% \text { of herbal mix }\end{array}$ & CV (\%) & $\mathrm{P}$ \\
\hline \multicolumn{8}{|l|}{ Stomach } \\
\hline $9^{\text {th }}$ day & 3.17 & 3.70 & 2.87 & 2.79 & 3.40 & 7.22 & 0.2606 \\
\hline $20^{\text {th }}$ day & $3.12 \mathrm{ab}$ & $2.76 \mathrm{ab}$ & $2.04 \mathrm{~b}$ & $2.56 \mathrm{ab}$ & $3.72 \mathrm{a}$ & 8.76 & 0.0388 \\
\hline \multicolumn{8}{|l|}{ Cecum } \\
\hline $9^{\text {th }}$ day & 5.94 & 5.64 & 6.11 & 5.51 & 5.74 & 5.42 & 0.1162 \\
\hline $20^{\text {th }}$ day & 5.55 & 5.53 & 5.65 & 5.67 & 5.69 & 4.62 & 0.8643 \\
\hline
\end{tabular}

${ }^{1}$ Means followed by different letters differ by SNK test $(\mathrm{P}<0.05)$.

$\mathrm{CV}=$ coefficient of variation. 
Table 5 - Morphometry of the jejunum of piglets on the $9^{\text {th }}$ and $20^{\text {th }}$ day of nursery receiving different experimental diets

\begin{tabular}{|c|c|c|c|c|c|c|c|}
\hline Variable $^{1}$ & $\begin{array}{l}\text { Without } \\
\text { addictive }\end{array}$ & Antibiotic & $\begin{array}{l}\text { Symbiotic } \\
\operatorname{mix}\end{array}$ & $\begin{array}{c}\text { Symbiotic mix }+ \\
0.05 \% \text { of herbal mix }\end{array}$ & $\begin{array}{c}\text { Symbiotic mix }+ \\
0.1 \% \text { of herbal mix }\end{array}$ & CV (\%) & $\mathrm{P}$ \\
\hline Villous $9^{\text {th }}$ day $(\mu \mathrm{m})$ & $311 b$ & $365 a$ & $336 a$ & $352 \mathrm{a}$ & $300 \mathrm{~b}$ & 8.38 & 0.0318 \\
\hline Villous $20^{\text {th }}$ day $(\mu \mathrm{m})$ & 474 & 509 & 429 & 498 & 475 & 9.48 & 0.1825 \\
\hline Crypt $9^{\text {th }}$ day $(\mu \mathrm{m})$ & 185 & 205 & 181 & 180 & 156 & 16.61 & 0.3200 \\
\hline Crypt $20^{\text {th }}$ day $(\mu \mathrm{m})$ & $272 b$ & $308 a$ & $303 a$ & $321 \mathrm{a}$ & $275 b$ & 7.19 & 0.0270 \\
\hline Villous:Crypt $9^{\text {th }}$ day & 1.70 & 1.87 & 1.88 & 1.99 & 2.00 & 15.95 & 0.6443 \\
\hline Villous:Crypt $21^{\text {th }}$ day & $1.74 \mathrm{a}$ & $1.66 \mathrm{a}$ & $1.42 \mathrm{~b}$ & $1.56 \mathrm{~b}$ & $1.74 \mathrm{a}$ & 8.74 & 0.0320 \\
\hline
\end{tabular}

${ }^{1}$ Means followed by different letters differ by SNK test $(\mathrm{P}<0.05)$.

$\mathrm{CV}=$ coefficient of variation.

Table 6 - Fecal score (\%) of post-weaning piglets fed different diets

\begin{tabular}{ccccccc}
\hline Score $^{1}$ & $\begin{array}{c}\text { Without } \\
\text { addictive }\end{array}$ & Antibiotic & $\begin{array}{c}\text { Symbiotic } \\
\text { mix }\end{array}$ & $\begin{array}{c}\text { Symbiotic mix }+ \\
0.05 \% \text { of herbal mix }\end{array}$ & $\begin{array}{c}\text { Symbiotic mix }+ \\
0.1 \% \text { of herbal mix }\end{array}$ \\
\hline 0 & $28 \mathrm{~b}$ & $48 \mathrm{a}$ & $30 \mathrm{~b}$ & $40 \mathrm{a}$ & $28 \mathrm{~b}$ & 25 \\
1 & 28 & 32 & 22 & 28 & $28 \mathrm{a}$ & 0.0089 \\
2 & $21 \mathrm{a}$ & $15 \mathrm{~b}$ & $24 \mathrm{a}$ & $18 \mathrm{~b}$ & 0.0051 \\
3 & $23 \mathrm{a}$ & $5 \mathrm{~b}$ & $24 \mathrm{a}$ & $14 \mathrm{ab}$ & 0.0546 \\
\hline
\end{tabular}

${ }^{1}$ Means followed by different letters differ by Kruskal-Walis test $(\mathrm{P}<0.05)$.

antibiotics inasmuch as the appropriate concentration is used.

As for the fecal score during the experimental period, the symbiotic combination of antibiotics and $0.05 \%$ of herbal extracts improved $(\mathrm{P}<0.05)$ the feces conditions because it has improved its consistency (firmer stool) $(\mathrm{P}<0.01)$ and decreased the diarrhea incidence $(\mathrm{P}<0.05$; Table 6).

Growth promoting additives can act on the animal organism by reducing the microbial population, decreasing the fermentation of carbohydrates and the incidence of diarrhea (Anderson et al., 1999). At this stage of the animal production, reducing the incidence of diarrhea reflects the improvement of the physiological and immunological characteristics, ensuring best performance.

\section{Conclusions}

The use of $0.3 \%$ of symbiotic associated to $0.05 \%$ of herbal mix showed the best results when compared to other associations of these products and the diets without antibiotics. However, when these results are compared to the diets added with antibiotics, further studies should be conducted to obtain more information about it, especially when it replaces them in the nursery phase.

\section{Akcnowledgements}

The authors gratefully acknowledge the INCTCA (Instituto Nacional de Ciência e Tecnologia - Ciência Animal).

\section{References}

ALEXOPOULOS, C.; GEORGOULAKIS, I.E.; TZIVARA, A. et al. Field evaluation of the efficacy of a probiotic containing Bacillus licheniformis and Bacillus subtilis spores, on the health status and performance of sows and their litters. Journal of Animal Physiology and Animal Nutrition, n.88, p.381-392, 2004.

ANDERSON, D.B.; McCRACKEN, V.J.; AMINOV, R.I. et al. Gut microbiology and growth-promoting antibiotics in swine. Pig News Information, v.20, p.115N-122N, 1999.

BUDIÑO, F.E.L.; THOMAZ, M.C.; KRONKA, R.N. et al. Efeito da adição de probiótico e/ou prebiótico em dietas de leitões desmamados sobre o desempenho, incidência de diarréia e contagem de coliformes totais. Brazilian Journal of Veterinary Research and Animal Science, v.43, p.59-67, 2006 (supl.).

CHESSON, A. Probiotics and other intestinal mediators. In: COLE, D.J.A. et al. (Eds.) Principles of pig science. Nottingham: University Press, 1994. p.197-214.

DORMAN, H.J.D.; DEANS, S.G. Antimicrobial agents from plants: antibacterial activity of plant volatile oils. Journal of Applied Microbiology, v.88, p.308-316, 2000.

ESTIENNE, M.J.; HARTSOCK, T.; HARPER, A.F. Effects of antibiotics and probiotics on suckling pig and weaned pig performance. International Journal of Applied Research in Veterinary Medicine, v.3, n.4, p.303-308, 2005.

FUKAYAMA, E.H.; BERTECHINI, A.G.; GERALDO, A. et al. Extrato de orégano como aditivo em rações para frangos de corte. Revista Brasileira de Zootecnia, v.34, n.6, p.2316-2326, 2005.

FULLER, R. Probiotics in man and animals. Journal of Applied Bacteriology, v.66, p.365-378, 1989.

HERMANN, J.R.; HONEYMAN, M.S.; ZIMMERMAN, J.J. et al. Effect of dietary Echinacea purpurea on viremia and performance in porcine reproductive and respiratory syndrome virus-infected nursery pigs. Journal of Animal Science, v.81, p.2139-2144, 2003.

JAMROZ, D.; KAMEL, C. Plant extracts enhance broiler performance. Journal of Animal Science, v.80, p.41, 2002 (suppl. 1). 
JUNQUEIRA, L.C.U.; JUNQUEIRA, L.M.M.S. Técnicas básicas de citologia e histologia. São Paulo: USP, 1983. 123p.

LAMBERT, R.J.W.; SKANDAMIS, P.N.; COOTE, P.J. et al. A study of the minimum inhibitory concentration and mode of action of oregano essential oil, thymol and carvacrol. Journal of Applied Microbiology, v.91, p.453-462, 2001.

LEE, K.W.; EVERTS, H.; KAPPERT, H.J. et al. Effects of dietary essential oil components on growth performance, digestive enzymes and lipid metabolism in female broiler chickens. British Poultry Science, v.44, n.3, p.450-457, 2003.

LEWIS, M.R.; ROSE, S.P.; MACKENZIE, A.M. et al. The effects of dietary herbal extracts for broiler chickens. Journal of Animal Science, v.82, suppl. 1, p.169, 2004.

MENTEN, J.F.M. Aditivos alternativos na nutrição de aves: probióticos e prebióticos. In: REUNIÃO ANUAL DA SOCIEDADE BRASILEIRA DE ZOOTECNIA, 38., 2001, Piracicaba: Anais... Piracicaba: SBZ, 2001. p.141-157.

NAMKUNG, H.; LI, M.; GONG, J. et al. Impact of feeding blends of organic acids and herbal extracts on growth performance, gut microbiota and digestive function in newly weaned pigs. Canadian Journal of Animal Science, v.84, n.4, p.697-704, 2004.

OETTING, L.L.; UTIYAMA, C.E.; GIANI, P.A. et al. Efeitos de extratos vegetais e antimicrobianos sobre a digestibilidade aparente, o desempenho, a morfometria dos órgãos e a histologia intestinal de leitões recém-desmamados. Revista Brasileira de Zootecnia, v.35, n.4, p.1389-1397, 2006.
PEDROSO, A.A.; OETTING, L.L.; UTIYAMA, C.E. et al. Variabilidade espacial da comunidade bacteriana intestinal de suínos suplementados com antibióticos ou extratos herbais. Revista Brasileira de Zootecnia, v.34, n.4, p.1225-1233, 2005.

ROSTAGNO, H.S.; ALBINO, L.F.T.; DONZELE, J.L. et al. Tabelas brasileiras para aves e suínos: composição de alimentos e exigências nutricionais. 2.ed. Viçosa, MG: UFV, 2005. 186p.

SANCHES, A.L.; LIMA, J.A.F.; FIALHO, E.T. et al. Utilização de probiótico, prebiótico e simbiótico em rações de leitões ao desmame. Ciência e Agrotecnologia, v.30, n.4, p.774-777, 2006.

SANTURIO, J.M.; SANTURIO, D.F.; POZZATTI, P. et al. Atividade antimicrobiana dos óleos essenciais de orégano, tomilho e canela frente a sorovares de Salmonella enterica de origem avícola. Ciência Rural, v.37, n.3, p.803-808, 2007.

STATISTICAL ANALYSIS SYSTEM - SAS. User's guide. version 6.12, 4.ed, v.2, Cary: 1998. 842p.

UTIYAMA, C.E.; OETTING, L.L.; GIANI, P.A. et al. Efeitos de antimicrobianos, prebióticos, probióticos e extratos vegetais sobre a microbiota intestinal, a freqüência de diarréia e o desempenho de leitões recém-desmamados. Revista Brasileira de Zootecnia, v.35, n.6, p.2359-2367, 2006.

VASSALO, M.; FIALHO, E.T.; OLIVEIRA, A.I.G et al. Probióticos para leitões dos 10 aos $30 \mathrm{~kg}$ de peso vivo. Revista Brasileira de Zootecnia, v.26, n.1, p.131-138, 1997.

WANG, R.; LI, D.; BOURNE, S. Can 2000 years of herbal medicine history help us solve problems in year 2000? In: ALLTECH'S ANNUAL SYMPOSIUM, 14., 1998, Nottingham. Proceedings... Nottingham: ALLTECH, 1998. p.168-184. 